\title{
Penguatan Landasan Teologis: \\ Pola Mewujudkan Moderasi Kehidupan Beragama
}

\section{The Strengthening of Theologhical Foundation: A Pattern for Embodying Religious Life Moderation}

\author{
Abdul Rouf \\ Institut PTIQ Jakarta \\ Email: abdulrouf16@yahoo.com \\ Artikel diterima 05 Februari 2020, diseleksi 20 Mei 2020, \\ dan disetujui 05 Juli 2020
}

Abstrak: Tulisan ini mencoba mengungkapkan realitas keberagaman sosial di Indonesia dengan segala problematika dan upaya perawatannya. Penelitian ini dilakukan dengan menggunakan penelitian kualitatif dengan pendekatan deskriptif, yaitu mendeskripsikan hasil penelitian sesuai dengan tujuan penelitian dan diikuti oleh analisis data untuk mendapat data yang relevan dan akurat. Dengan pendekatan kualitatif-deskriptif-analitis, tulisan ini mengkaji suatu perspektif al-Qur'an melalui ayat-ayat-nya tentang konsep satu pola mewujudkan moderasi hidup beragama melalui penguatan pada segi teologis hubungan muslim non-muslim dan pemahaman agama yang pluralis dan inklusif untuk mendukung upaya mewujudkan sikap keterbukaan dan toleran. Dengan demikian, aspek toleransi mempunyai peran penting dari kerja sama pemerintah dan para tokoh agama untuk mendukung akselerasi dari makna dan substansi toleransi yang ditransformasikan ke dalam kehidupan sosial kemasyarakatan, sehingga konflik secara horizontal dapat dihindarkan dengan pola hidup yang moderat.

Kata Kunci: Moderasi, Ekstremisme, Liberalisme, Toleransi, Inklusif 
Abstract: This study aims to reveal the social diversity reality in Indonesia with all its problems and solutions. The method in this research is used the qualitative method with a descriptive approach to describe the study results in accordance with the study objectives then followed by data analysis to obtain an appropriate and accurate research findings. With a qualitative-descriptiveanalytical approach, this study examines the Qur'an perspective through its verses on the concept of a pattern for embodying the religious life moderation in order to promote unity of the nation and state through the strengthening theological aspects of Muslim and non-Muslim relations as well as pluralistic and inclusive understandings in accepting openness and tolerance. Tolerance has an important role of cooperation between the government and religious leaders to accelerate the tolerance implementation that is transformed into social life avoiding horizontal conflict in a moderate manner.

Keywords: Moderation, Extremism, Liberalism, Tolerance, Inclusive

\section{A. Pendahuluan}

Salah satu argumen penting hadirnya moderasi beragama, khususnya di Indonesia, adalah fakta masyarakat Indonesia yang sangat plural dan multikultural. Bangsa kita terdiri dari beragam suku, etnis, agama, bahasa dan budaya. Indonesia dikenal sebagai salah satu negara multikultur dan majemuk terbesar di dunia selain Amerika Serikat dan India. Hal ini dapat dilihat dari kondisi geografis dan sosio-kultural Indonesia yang beragam, kompleks dan luas.

Di samping itu, bangsa Indonesia memiliki karakter yang ramah, tolong menolong, saling menghormati dan menjunjung prinsip $\mathrm{ke}$ bhinneka-an. Namun demikian bukan berarti bangsa Indonesia tidak menghadapi permasalahan SARA. Toha dkk mencatat, pada tahun 1996 terjadi beberapa kali peristiwa konflik yang bernuansa sosial maupun agama, seperti kerusuhan di Situbondo tanggal 10 Oktober 1996, di Tasikmalaya 26 Desember 1996, di Karawang tahun 1997 dan 
Tragedi Mei pada tanggal 13-15 Mei 1998, yang terjadi di Jakarta, Solo, Surabaya, Palembang, Medan, beserta peristiwa-peristiwa kerusuhan lainnya. ${ }^{1}$ Sementara itu, data dari Kemenag menambahkan peristiwa Jalan Ketapang Jakarta, kerusuhan di Kupang yang menyebarke Ambon (Januari 1999), Ujung Pandang (1 April 1999), disusul konflik antar-etnis di Sambas Kalimantan Barat 1999, konflik Poso, dan Maluku Utara. ${ }^{2}$

Peristiwa pembakaran gereja di Halmahera pada 14-15 Agustus 2002, konflik Poso pada Desember 2003, penyerangan terhadap Huriah Kristen Batak Protestan (H.K.B.P) dan penyerangan terhadap rumah-rumah pengikut Ahmadiyah di Lombok pada September 2002, adalah bagian dari kasus- kasus konflik yang melibatkan unsur agama di dalamnya. ${ }^{3}$

Zuhairi Misrawi, menyatakan bahwa lembaganya (Moderate Muslim Society/MMS) pada Desember 2010 telah mencatat terjadi 81 kasus intoleransi, meningkat 30 persen dari laporan tahun 2009 yang mencatat 59 kasus. Lebih lanjut dikatakan, dari 81 kasus tersebut, jenis kasus yang paling sering terjadi adalah 24 kasus penyerangan dan perusakan, 24 kasus penutupan dan penolakan rumah ibadah, 15 kasus ancaman, tuntutan dan intimidasi. Kemudian 6 kasus penghalangan kegiatan ibadah, 4 kasus diskriminasi karena keyakinan, 3 kasus pembubaran kegiatan atas nama agama, 3 kasus kriminalisasi paham keagamaan dan 2 kasus pengusiran. Dari segi wilayah atau tempat, sepanjang tahun 2010 tindakan intoleransi paling banyak terjadi di wilayah Jawa Barat dengan 49 kasus, Jawa Timur dengan 6 kasus, DKI dengan 4 kasus dan Sulawesi Selatan dengan 4 kasus. ${ }^{4}$

Sementara menurut Tedi, Direktur Lembaga Studi Sosial dan Agama Semarang (eLSA), pada semester pertama tahun 2014 ada 6 kasus kekerasan bernuansa agama atau intoleransi yang terjadi di Jawa Tengah. Keenam kasus tersebut adalah perusakan tempat sembahyang umat Hindu di Sragen, bentrok warga dengan FPI di Wonosobo, pembubaran Pengajian Majelis Tafsir al-Qur'an (MTA) di Demak, penolakan kedatangan Habib Rizieq di Demak, permasalahan pengajian 
Jantiko Mantab oleh Camat Grobogan, dan penangkapan terduga teroris di Klaten. Menurut eLSA, enam kasus itu patut dicermati. Sebab secara substansi, kasus intoleransi jenis itu bukan hal baru, seperti konflik yang melibatkan FPI yang mirip dengan yang terjadi di Kendal. Hanya motivasinya yang berbeda. ${ }^{5}$

Menurut Abu Hapsin, Komarudin, M. Arja Imroni ${ }^{6}$ bahwa konflik antar umat beragama akan terus berlangsung, hal itu dikarenakan antara lain: (1) menguatnya radikalisme, fundamentalisme dan terorisme; (2) belum optimalnya kedewasaan masyarakat dalam beragama. D itambah peran serta masyarakat yang rendah dalam menjaga toleransi agama; (3) belum adanya pelaksanaan dari UUD Negara Republik Indonesia pasal 29; (4) penegakan hukum yang mengalami kegamangan jika terjadi konflik keagamaan.

Terlihat sekali keberadaan sebuah konflik ditimbulkan oleh adanya sebuah perbedaan dalam kehidupan masyarakat. Perbedaan itu tidak dipersepsikan sebagai sebuah kemanfaatan di dalam kehidupannya, namun dipersepsikan sebagai bentuk penolakan terhadap perbedaan itu sendiri.

Realitas tersebut menunjukan betapa pentingnya mencarikan jalan keluar yang dapat melepaskan diri dari potensi konflik dan ekstremisme dengan memunculkan pemahaman keagamaan yang bernuansa damai, toleran, inklusif, pluralis dan sejuk serta menguntungkan bagi semua pihak dengan menempatkan konsep moderasi kehidupan beragama sebagai solusi dengan melakukan penguatan landasan teologisnya demi mewujudkan sikap keterbukaan sehingga kehidupan berbangsa dan bernegara dapat dijalani secara produktif dan harmonis.

Karena sejatinya, perbedaan mempunyai aktualisasi yang membawa kemanfaatan bagi kehidupan sosial masyarakat, misalnya tolong menolong antar sesama, bekerjasama dalam berbagai kebutuhan, menciptakan stabilitas saling menghargai satu sama lain, dan menciptakan kondisi lingkungan kehidupan sosial yang lebih baik dan 
berkualitas, untuk kemaslahatan dan kesejahteraan bagi seluruh warga negara.

\section{B. Hasil dan Pembahasan}

\section{Diskursus Seputar Makna Moderasi}

Arti moderasi dalam bahasa Arab dikenal dengan kata wasath atau wasathiyah, yang memiliki padanan makna dengan kata tawassuth (tengahtengah), i'tidal (adil), dan tawazun (berimbang). Orang yang menerapkan prinsip wasathiyah bisa disebut wasith. Dalam bahasa Arab pula, kata wasathiyah diartikan sebagai "pilihan terbaik". Apa pun kata yang dipakai, semuanya menyiratkan satu makna yang sama, yakni adil, yang dalam konteks ini berarti memilih posisi jalan tengah di antara berbagai pilihan ekstrem. Kata wasith bahkan sudah diserap ke dalam bahasa Indonesia menjadi kata 'wasit' yang memiliki tiga pengertian, yaitu:1) penengah, perantara (misalnya dalam perdagangan, bisnis); 2) pelerai (pemisah, pendamai) antara yang berselisih; dan 3) pemimpin di pertandingan. ${ }^{7}$

Adapun lawan kata moderasi adalah berlebihan (guluw), atau tatharruf dalam bahasa Arab. Dalam bahasa Inggris-nya mengandung makna extreme, radical, dan excessive. Kata extreme juga bisa berarti "berbuat keterlaluan, pergi dari ujung ke ujung, berbalik memutar, mengambil tindakan/ jalan yang sebaliknya". Dalam bahasa Arab, setidaknya ada dua kata yang maknanya sama dengan kata extreme, yaitu al-guluw, dan tasyaddud. Meski kata tasyaddud secara harfiyah tidak disebut dalam al-Qur'an, namun turunannya dapat ditemukan dalam bentuk kata lain, misalnya kata syadid, syidad, dan asyadd. Ketiga kata ini memang sebatas menunjuk kepada kata dasarnya saja, yang berarti keras dan tegas, tidak ada satu pun dari ketiganya yang dapat dipersepsikan sebagai terjemahan dari extreme atau tasyaddud. Dalam konteks beragama, pengertian "berlebihan" ini dapat diterapkan untuk merujuk pada orang yang bersikap ekstrem, serta melebihi batas 
dan ketentuan syariat agama. ${ }^{8}$

Karenanya, moderasi beragama mesti dipahami sebagai sikap beragama yang seimbang antara pengamalan agama sendiri (eksklusif) dan penghormatan kepada praktik beragama orang lain yang berbeda keyakinan (inklusif). Keseimbangan atau jalan tengah dalam praktik beragama niscaya akan menghindarkan dari sikap ekstrem, berlebihan, fanatik dan sikap revolusioner dalam beragama.

Moderasi beragama dengan menolak ekstremisme dan liberalisme dalam beragama adalah kunci keseimbangan, demi terpeliharanya peradaban dan terciptanya perdamaian. Dengan cara inilah masingmasing umat beragama dapat memperlakukan orang lain secara terhormat, menerima perbedaan, serta hidup bersama dalam damai dan harmoni. Dalam masyarakat multikultural seperti Indonesia, moderasi beragama bisa jadi bukan pilihan, melainkan kemestian.

\section{Dari Ektremisme ke Modernisme}

Seringkali dipahami bahwa gerakan moderasi itu hanya berkutat pada penanganan masalah konservatisme beragama, atau yang sering disebut sebagai ekstrem kanan. Padahal sejatinya tidak hanya bertujuan untuk menengahi mereka yang cenderung memiliki pemahaman keagamaan yang ultrakonservatif, melainkan juga kelompok yang memiliki cara pandang, sikap, dan perilaku beragama yang liberal, atau yang sering disebut sebagai ekstrem kiri.

Salah satu contoh yang lagi viral saat ini adalah kasus pandangan keagamaan seorang sarjana Muslim yang menghalalkan hubungan seks di luar nikah misalnya. Ini adalah contoh tafsir liberal yang dapat dikategorikan sebagai ekstrem kiri. Meski tafsir ini juga didasarkan pada teks al-Qur'an tentang milk al-yamin (hamba 
sahaya/budak). Namun penerapannya dalam konteks sekarang dianggap oleh sebagian besar tokoh agama sudah terlalu jauh keluar dari maksud teks alias liberal. Karena secara kultural tradisi perbudakan sudah dihilangkan.

Sebaliknya, pandangan keagamaan yang hitam putih dalam memahami teks agama juga seringkali terjebak pada sisi ekstrem lain yang merasa benar sendiri. Dalam konteks beragama, pandangan, sikap, dan perilaku ekstrem seperti iniakanmendorong pemeluknya untuk menolak menerima pandangan orang lain, dan bersikukuh dengan tafsir kebenarannya sendiri. Dari sinilah muncul terma "garis keras", ekstrem atau ekstremisme, yang dikaitkan dengan praktik beragama yang ultra-konservatif.

Dengan demikian, moderasi beragama tidak hanya bertujuan untuk menengahi mereka yang cenderung memiliki pemahaman keagamaan yang ultra- konservatif, melainkan juga kelompok yang memiliki cara pandang, sikap, dan perilaku beragama yang liberal.

Kekerasan dan sikap ekstremis bukanlah merupakan sebuah tawaran yang bijak untuk menyikapi polarisasi dunia akibat tamparan hebat modernitas. Islam memiliki banyak kerangka pemikiran untuk mewujudkan kedamaian di muka bumi.

Al-Quran tidak memerintahkan sikap tegas dan keras (ekstremitas) kecuali dalam dua tempat. Berikut ini penjelasan al-Qardhawi dalam bukunya Al-Shahwah; ${ }^{9}$

Di tengah-tengah medan peperangan, ketika berhadapan dengan musuh, yakni di saat siasat militer yang tepat mengharuskan sikap tegas dan keras serta menyisihkan perasaan lunak hingga selesainya peperangan. Dalam hal Allah SWT berfirman;

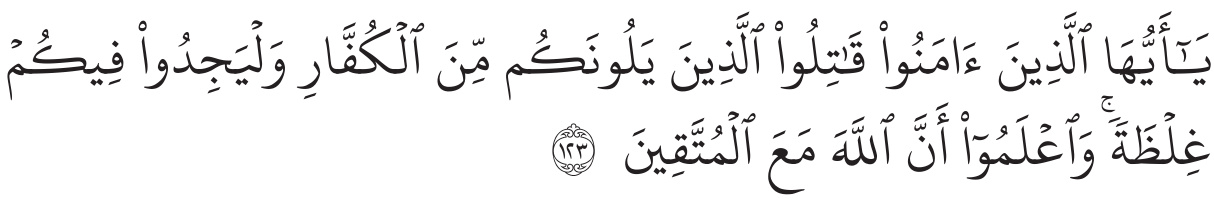


Artinya: "Hai orang - orang yang beriman, perangilah orang-orang kafir yang ada disekelilingmu, agar mereka mendapatkan kekerasan darimu. Ketahuilah sesungguhnya Allah bersama orang-orang yang bertakwa" (QS. AlTaubah/9:123).

Dalam melaksanakan sangsi hukum atas orang yang berhak menerimanya. Sesuai dengan firman-Nya;

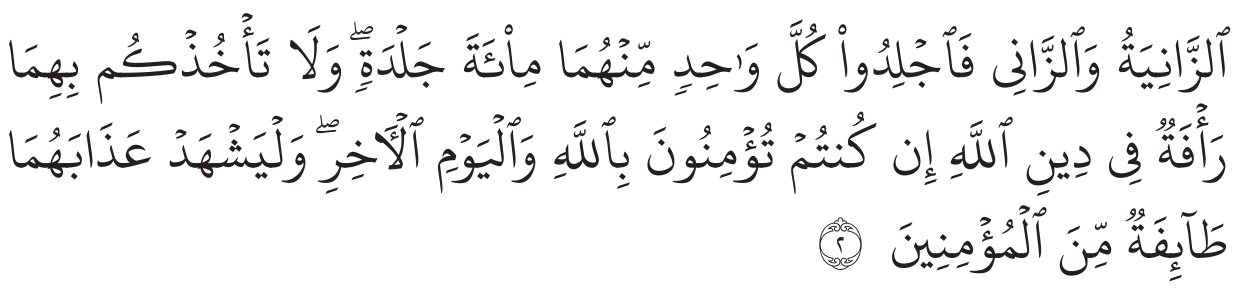

Artinya: "Perempuan yang berzina dan laki-laki yang berzina, Maka deralah tiap-tiap seorang dari keduanya seratus kali dera, dan janganlah belas kasihan kepada keduanya mencegah kamu untuk (menjalankan) agama Allah, jika kamu beriman kepada Allah, dan hari akhirat, dan hendaklah (pelaksanaan) hukuman mereka disaksikan oleh sekumpulan orang-orang yang beriman" (QS. AlNûr/24: 2)

Jelas sekali berdasarkan fakta di atas, bahwa tidak sembarangan bersikap ekstrem dan keras kecuali pada hal-hal yang dibenarkan alQuran. Ekstremitas dalam bahasa al-Quran disebut dengan istilah alghuluw (sikap berlebih-lebihan dalam agama). Dalam bahasa hadis disebut dengan istilah tanatthu' (berlebih-lebihan dalam agama) serta tashdîd (mempersulit diri). Sikap ini merupakan perbuatan yang sangat dilarang. Karena begitu bahayanya sikap ini, banyak sekali keterangan baik dari al-Quran maupun hadis Rasul SAW yang mengindikasikan larangan dan keharusan menghindari perbuatan tersebut.

Berikut ini beberapa ayat dan hadis Rasulullah SAW yang menjelaskan terkait dengan persoalan tersebut;

Diriwayatkan oleh Imam Ahmad dalam musnadnya, Al-Nasa'i dan Ibn Majah dalam kedua sunannya, serta al-Hakim dalam Mustadrak-nya, dari Abdullah bin Abbas ra. Bahwasannya Nabi bersabda; “Hindarilah 
sikap melampaui batas dalam agama, karena sesungguhnya orangorang sebelum kamu telah binasa karenanya. Yang dimaksud dengan "orang-orang sebelum kamu" pada hadis di atas dalam bukunya seperti dijelaskan al-Qardhawi dalam bukunya al-Shahwah bahwa para pemeluk agama terdahulu seperti Ahl al-Kitâb (Yahudi-Nasrani), khususnya kaum Nasrani. ${ }^{10} \mathrm{Al}$-Quran pun telah menunjukan celaan terhadap sikap guluw terkait dengan sikap kaum kristiani dalam firman-Nya;

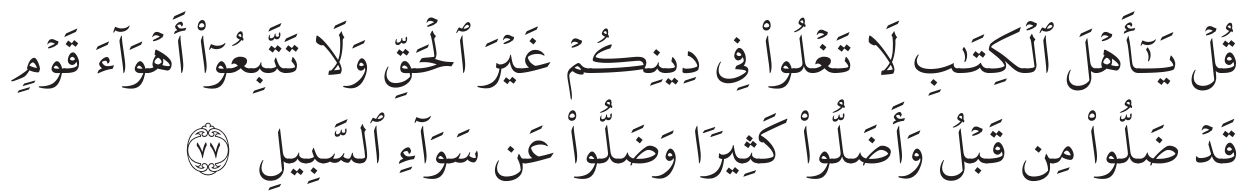

Artinya: "Katakanlah: Hai ahli kitab, janganlah kamu melampaui batas, selain kebenaran dalam agamamu. Dan jangan kamu mengikuti hawa nafsu dari suatu kaum sebelum-mu yang telah sesat dan menyesatkan banyak orang" (QS. Al-Maidah/5: 77)

Melihat kasus di atas, teringat sebuah peristiwa yang pernah terjadi antara Rasul dan salah seorang sahabatnya Ibn Abbas as. ketika sampai di Muzdalifah dalam haji wada',. Waktu itu Rasulullah saw. menyuruh Ibn Abbas mengambil batu kerikil untuk melempar jumrah di Mina. Kemudian Ibn Abbas as. mengambil batu-batu itu. Dan ketika Ibn Abbas menyerahkannya Rasulallah saw bersabda; "Suruhlah mereka mengambil batu kerikil yang kecil saja dan hindarkanlah sikap berlebihan dalam agama. Maksud hadis ini adalah tidak sepatutnya mereka bersikap berlebihan dengan mengatakan bahwa melempar jumrah dengan batu yang besar akan lebih sempurna dari pada melemparnya dengan batu kecil.

Terkait dengan Hadis di atas, Ibn Taimiyah berkata seperti dikutip al-Qardhawi bahwa larangan itu bersifat umum, baik yang berkenaan dengan akidah maupun perbuatan biasa. Kaum Nasrani adalah kaum yang paling banyak berbuat melampuai batas dalam keduanya. ${ }^{11} \mathrm{Hal}$ itu sesuai dengan firman Allah; "Wahai ahlul kitab, janganlah kau melampaui batas dalam agamamu" (QS. Al-Nisa/4: 171) 
2). Imam Muslim dalam kitab shahih-nya meriwayatkan, dari Abd Allah bin Mas'ud, ia berkata bahwa Rasulullah saw. bersabda; "Binasalah kaum mutanatthi'ûn", dan beliua mengulanginya sampai tiga kali. Imam Nawawi berkata; "Al-Mutanatthiûn adalah orag-orang yang sok berdalam-dalam ketika membahas (bertele-tele), hingga ucapan dan tindakan mereka melampaui batas dan berdalam-dalam ketika membahas, akibatnya terjatuh dalam kebinasaan, baik ukhrawi maupun duniawi. Adakah petaka lain dari kebinasaan? Kiranya cukuplah hal ini sebagai peringatan seperti dijelaskan al-Qardhawi dalam bukunya $\mathrm{Al}$ Shahwah. ${ }^{12}$

3). Abu Ya'la dalam musnadnya meriwayatkan dari Anas bin Malik bahwa Rasulullah saw. bersabda; “Janganlah kamu memperberat dirimu, nanti Allah memperberat atas kamu. Suatu kaum telah memberati diri mereka sendiri sehingga Allah memperberat atas mereka. Lihatlah sisasisa hal itu seperti dalam cara hidup para pendeta kaum Nasrani. Hadis tersebut dijelaskan al-Qardhawi dalam bukunya Al-Shahwah."13

Karenanya, Nabi sangat menentang setiap perbuatan yang berlebihan dalam beragama, dan melarang siapa pun yang bersikap berlebih-lebihan dalam peribadatan sampai keluar dari batas kebenaran yang telah diajarkan Islam. Atas dasar itu pula Islam tidak membenarkan hidup kerahiban yang mengharuskan manusia menjauhkan diri dari kehidupan dunia dan segala kenikmatan yang baik-baik. Islam mengajarkan hidup seimbang.

Dengan menyebutkan beberapa teks keagamaan di atas, bisa dikatakan bahwa Islam adalah Agama jalan tengah (al-Dîn al-Tawassuthî). Islam adalah agama yang selalu mengajarkan konsep keseimbangan atau jalan tengah dalam segala hal, baik dalam hal konsep, akidah, ibadah, perilaku, hubungan sesama manusia maupun dalam perundang - undangan.

Sikap tengah (moderat) merupakan salah satu ciri ajaran Islam yang tidak didapati dalam agama-agama sebelumnya (Agama Yahudi dan Nasrani). Allah berfirman; 


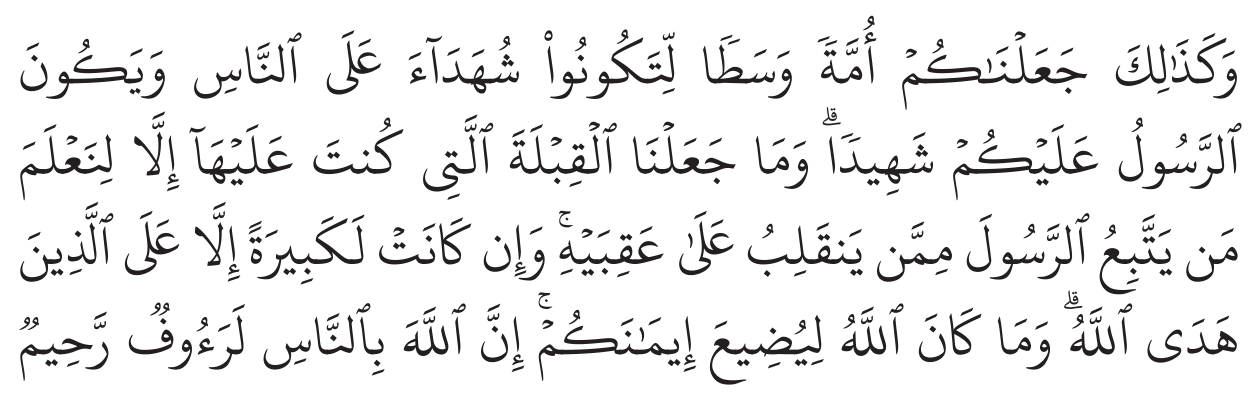

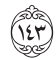

"Dan demikian (pula) kami Telah menjadikan kamu (umat Islam), umat yang adil dan pilihan (tengah - tengah) agar kamu menjadi saksi atas (perbuatan) manusia..." (QS. Al-Baqarah/2: 143)

Dalam ayat di atas ditegaskan bahwa umat Islam yang mempunyai ciri moderat dan toleran, akan menjadi saksi atas segenap umat manusia. Sikap moderat dan toleran ini pernah dipraktekkan oleh muslim klasik. Mereka amat terbuka terhadap pemikiran dan budaya lain. Penulis melihat ayat tersebut di atas sangat terkait dengan penanganan terhadap gejala radikalisme saat ini.

Karenanya, tidak berlebihan jika ingin mengurangi sikap radikalisme di negeri Indonesia, semestinya mengambil langkah kongkrit dengan cara merevitalisasi spirit Islam zaman klasik. ${ }^{14}$ Karena model Islam yang seperti inilah yang cocok untuk konteks Indonesia yang heterogen. Tentu saja Islam klasik yang dimaksud di sini tidak dimaknai secara definitif, tapi lebih mengacu kepada sikap dan moralitas Islam yang dianut muslim klasik yang sangat toleran dan moderat dalam menghadapi fenomena keberagaman pemahaman dan keyakinan serta mampu mengakomodasi nilai-nilai klasik.

Pada Islam zaman klasik, perbedaan tidak mesti harus disikapi dengan permusuhan karena hal itu hanya akan menciptakan permusuhan yang baru. Perbedaan harus disikapi dengan cara bijak dan saling menghormati. Prinsip ini bisa diamati dengan jelas dalam warisan intelektualitas Islam klasik yang sangat plural dan beragam pendapat 
dimana yang satu tak pernah menyalahkan yang lainnya. Implementasi dari cara berpikir yang bernas ini, membuat muslim klasik tidak hanya berpegang pada satu mazhab pemikiran saja, tapi juga mengakomodasi mazhab pemikiran lainnya.

Demikian pula dalam menyikapi fenomena kejahatan (kemaksiatan) baik secara individual maupun sosial. Islam model ini tidak mengedepankan pendekatan emosional dan kekerasan, karena pendekatan tersebut tidak akan mampu menyelesaikan masalah secara tuntas. Kejahatan (kemaksiatan) itu senantiasa ada sepanjang perjalanan sejarah manusia dan ia akan selalu mendapatkan ruang dan salurannya.

Oleh karena itu, kejahatan itu dihancurkan secara bertahap. Sikap yang emosional dan reaksioner dalam menyikapi kemaksiatan hanya akan membuat kemaksiatan itu senantiasa tumbuh dan berkembang. Muslim klasik dalam menyikapi fenomena ini lebih mengedepankan pendekatan kultural dan dakwah individual. Pelaku kriminal tidak harus dimusuhi dan dijauhi, tapi harus didekati secara persuasif untuk selanjutnya diberikan pembinaan moralitas secara intensif sehingga tumbuh kesadaran penuh untuk memperbaiki diri.

Pertanyaan yang muncul kemudian adalah adakah dasar-dasar dan batasan ekstremitas keagamaan (al-Tatharruf al-Dînî). Karena kalau tidak dijelaskan, bisa jadi orang yang benar-benar komitmen terhadap ajaran agamanya, berpegang teguh kepada adat - istiadat yang Islami dalam makan, minum, berpakaian, berhias dan sebagainya sebagai sikap keterlaluan dan ekstrem. Karena ada sebagian orang beranggapan bahwa pemuda yang memelihara janggutnya atau pemudi yang berkerudung sebagai bentuk ekstrim dalam beragama. Dan sebagian orang juga beranggapan terhadap sikap orang yang membela kesucian dan kehormatan agama, amr bin ma'ruf dan nahy 'an al-munkar (menyeru kebaikan dan melarang berbuat mungkar), juga dianggap sebagai sikap ekstrem dalam beragama. Saya kira jika semua sikap seperti itu dianggap ekstremitas dalam agama, sangat tidak adil. Tidak boleh seseorang 
dituduh sebagai ekstrem dalam agamanya semata - mata karena ia memilih salah satu pendapat di antara pendapat-pendapat fikih yang agak keras (ketat) sekalipun, selama ia percaya bahwa itu lebih benar dan lebih baik.

Dalam persoalan ini, cukuplah seorang Muslim menyandarkan pendapatnya kepada salah satu di antara beberapa mazhab, berpegang pada ijtihad (hasil penelitian) yang ditegakkan atas petunjuk dalil-dalil syara' yang benar. Apabila ada di antara imam-imam mazhab yang diikuti, ada yang menyatakan wajibnya menumbuhkan janggut dan membiarkannnya panjang serta haram mencukurnya; apakah orang yang melaksanakan dan berpegang pada mazhab itu, boleh dicap sebagai ekstrem, semata-mata karena berbeda pendapat dengan aku atau anda, atau pendapat si fulan atau si fulan di kalangan para ulama (terutama mereka yang hidup masa kini)? Apakah termasuk hak kita untuk merampas hak seseorang dalam membenarkan suatu pendapat atas mazhab lain, apalagi dia hanya menerapkan suatu mazhab bagi kehidupan orang lain?. Bukan hak kita, memaksa seseorang agar menjauhkan diri dari pendapat yang dipercayainya atau menuntutnya agar mengikuti cara-cara yang bertentangan dengan keyakinannya. Tapi, seyogyanya yang perlu dilakukan ialah menyeru kepada apa saja yang kita anggap paling benar, dengan penuh bijaksana, dan mengajak berdialog dengan cara yang baik, serta memuaskan setiap orang dengan dalil-dalil yang tepat.

Kalau begitu apa ekstremitas itu? Apa ada ciri-ciriya? Dan sekaligus juga apabila ciri ini tidak didapati pada seseorang, maka dia bisa dikatakan sebagai pemeluk agama yang moderat. Terkait dengan masalah ini, Yusuf al-Qardhawi menjelaskan paling tidak ada sekitar empat ciri sikap ekstremisme yaitu, ${ }^{15}$

\section{a). Mempersukar Diri Dalam Melakukan Kewajiban}

Tanda-tanda lain dari sikap ekstremisme keagamaan adalah selalu memilih sesuatu yang sukar pada hal-hal yang sebenarnya terdapat 
kemudahan dan mewajibkan kepada orang lain untuk mengerjakan yang sulit itu, padahal Allah tidak mewajibkannya.

Memang tak ada larangan bagi seseorang berpegangan pada yang lebih sukar atau lebih berat dalam beberapa masalah untuk diri sendiri, sebagai bentuk kehatia-hatian. Namun, tidaklah baik orang terus menerus dalam keadaan demikian sehingga di saat memerlukan kemudahan enggan melakukannya. Dan walaupun telah diberi kelonggaran ia tetap menolaknya.Padahal Rasullah saw. bersabda; "Mudahkanlaholehmu dan jangan mempersulit. Gembirakanlah mereka jangan menyusahkannya'. Dalam hadis lain disebutkan; "sesungguhnya Allah swt. menyukai orang yang memanfaatkan kemudahan-Nya sebagaimana Ia tidak menyukai orang berbuat maksiat kepada-Nya."

Firman Allah SWT;

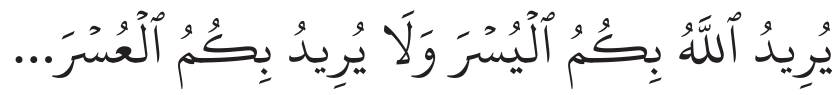

Artinya: "Sesungguhnya Allah menghendaki kemudahan bagimu dantidak menghendaki kesukaran" (QS. Al-Baqarah/2: 185)

Dalam sebuah hadis sahih disebutkan "Rasulullah apabila dihadapkan dengan dua perkara, beliau selalu memilih yang lebih mudah diantara keduanya, selama tidak mendatangkan dosa". ${ }^{16}$

Ibn Mas'ud Al-Anshari berkata; "Seorang laki-laki mengadu kepada Rasulullah saw. 'Ya Rasulullah, aku terpaksa tidak salat subuh berjamaah, karena si fulan biasa memanjangkan bacaan salat. Mendengar pernyataan laki-laki itu Rasulullah saw. sangat marah. Demikian kata Ibn Mas'ud. Kemudian beliau bersabda; "Wahai sekalian manusia, sesungguhnya di antara kamu terdapat orang-orang yang memberatkan. Barang siapa menjadi iman dalam salat bersama orang banyak, maka ringankanlah bacaannya, karena dibelakangnya terdapat orang yang lemah, lanjut usia, dan orang-orang yang mempunyai kepentingan." Ketika Mu'az memanjangkan salatnya bersama suatu kaum, Rasulullah saw. berkata kepadanya; “Hai Mu'az, apakah engkau hendak menimbulkan fitnah?” 
dan beliau mengulangi perkataan ini sampai tiga kali. Dan dari Anas, ia berkata; bahwasannya Nabi saw. bersabda; "Adakalanya aku hendak memanjangkan salatku, lalu kudengar tangis seorang anak sehingga kuringankan (memendekan) salatku karena aku mengetahui kegelisahan ibunya terhadap tangis anak itu". ${ }^{17}$

Termasuk di antara perbuatan yang memberatkan adalah memaksakan orang lain mengerjakan hal-hal yang sunnah, dengan mengangapnya seolah-olah wajib, dan menganggap yang makruh seolah-olah haram. Padahal, yang diharuskan ialah agar kita tidak mewajibkan sesuatu, kecuali yang telah diwajibkan oleh Allah swt. Adapun yag selebihnya, orang boleh memilihnya.

\section{b). Bersikap Kasar dan Keras}

Di antara tanda lain dari sikap ekstrem adalah bersikap kasar, keras, dan tidak berperangai halus dalam berkomunikasi dan berdakwah. Padahal Allah dan Rasul-Nya telah memerintahkan agar berdakwah dengan hikmah dan bukan dengan kejahilan, dengan pengajaran yang baik, bukan dengan ungkapan-ungkapan kasar; serta berdebat dengan menggunakan cara yang paling baik. Sesuai dengan firman Allah;

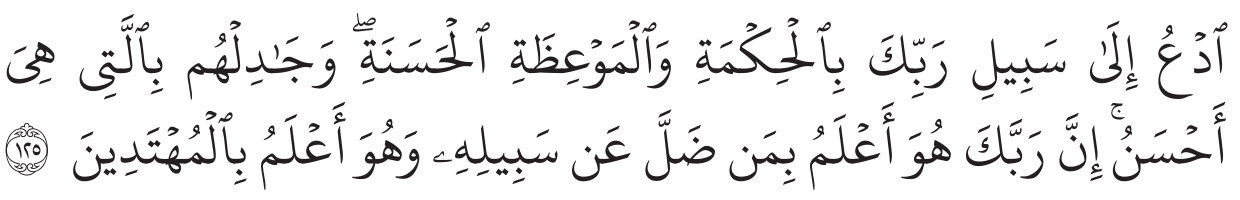

Artinya: "Serulah manusia kepada jalan Tuhan-Mu dengan hikmah dan nasehat yang baik, bahkan debatlah mereka dengan cara yang terbaik. Sesungguhnya Tuhanmu legih mengethui orang yang sesat dari jalan-Nya dan lebih mengetahui orang-orang yang mendapat petunjuk" (QS. Al-Nahl /16: 125)

Rasulullah pun menunjukan sikapnya dengan para sahabatnya seperti firman Allah SWT berikut ini; 


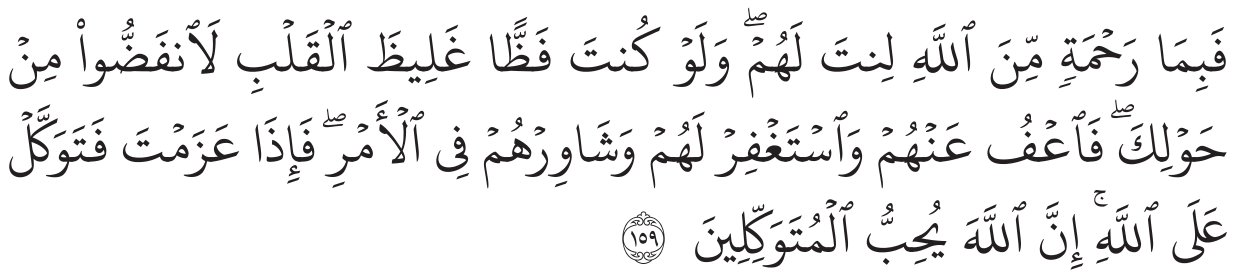

Artinya: "Maka disebabkan rahmat dari Allah-lah kamu berlaku lemah lembut terhadap mereka. sekiranya kamu bersikap keras lagi berhati kasar, tentulah mereka menjauhkan diri dari sekelilingmu. Karena itu ma>afkanlah mereka, mohonkanlah ampun bagi mereka, dan bermusyawaratlah dengan mereka dalam urusan itu. Kemudian apabila kamu Telah membulatkan tekad, Maka bertawakkallah kepada Allah. Sesungguhnya Allah menyukai orang orang yang bertawakkal kepada-Nya" (QS. Al- Imran/3: 159)

Dengan demikian, tidak semestinya dalam berdakwah berlaku keras dan kasar. Dalam hadis shahih dari Aisyah ra. disebutkan; "Sesungguhnya Allah menyukai kelemah lembutan dalam segala perkara" ${ }^{18}$ Dalam Hadis sahih lain juga dari Aisyah ra. disebutkan", "Setiap kali sikap lemah dilakukan dalam suatu perkara, niscaya akan menjadikan baiknya perkara itu. Setiap kali sikap kasar itu dilakukan dalam suatu perkara, niscaya akan menjadikan buruknya perkara itu" (QS. Al- Imran/3: 159)

Hal itu semua mengindikasikan bahwa perilaku keras tidak pernah menghasilkan sesuatu kecuali keburukan.

3). Mudah Mengkafirkan

Sikap ekstrem yang tertinggi barangkali adalah sikap mudah mengkafirkan. Sikap ini sangat dilarang, karena orang yang sudah dikafirkan akan berimplikasi pada pengguguran hak kehormatan orang lain, dan menghalalkan jiwa dan harta mereka, serta tidak lagi melihat hak mereka untuk tidak diganggu dan hak diperlakukan secara adil. Hal ini akan terjadi ketika orang telah dikuasai kekacauan pikiran lalu menuduh kebanyakan orang telah keluar dari Islam. Sikap inilah yang dilakukan kelompok Khawarij pada masa permulaan Islam. Mereka ini termasuk 
sangat ketat dalam melaksanakan bermacam-macam ritus peribadatan seperti puasa, salat, dan baca al-Qur'an. Tetapi mereka sebenaranya telah terjerumus dalam kebinasaan disebabkan keburukan pikiran, bukan disebabkan keburukan hati. Hubungan Kelompok Khawarij dengan alQur'an dilukiskan Rasul dengan sabdanya; “Mereka membaca al-Qur'an, tetapi bacannya tidak melampaui kerongkongan". Di samping itu Rasul juga bersabda tentang ciri lain dari kelompok ini; "Mereka membunuh pemeluk agama Islam dan membiarkan penyembah berhala."

4). Fanatik Mazhab dan tidak mau mengakui pendapat lain

Fanatik mazhab di antara sikap ekstrem yang sangat menonjol. Sikap bersikeras atas suatu paham secara berlebihan dan tidak wajar, tidak mau melihat pendapat orang lain. Tidak memberikan peluang untuk berdiskusi adalah sikap yang amat dibenci dalam Islam. Karena para ulama sepakat bahwa setiap orang siapa saja, boleh diambil atau ditinggalkan pendapatnya, kecuali pendapat Nabi saw.

Memilik pendapat, meyakininya dan menyebarkannya tidak dilarang dalam Islam. Yang dilarang adalah menjadikan perbedaan pendapat itu sebagai bibit perpecahan atau untuk mengklaim bahwa pendapatnya satu-satunya kebenaran sementara yang lain salah.

Dalam menyikapi perbedaan, Yusuf al-Qardhawi Ulama asal Mesir ini mengatakan; "Kita harus sepakat pada yang qath'î dan siap berbeda pada yang zhannî. Harus sepakat pada yang qath'î artinya kita mesti melakukan fiqih prioritas dalam melakukan sesuatu, harus lebih mengutamakan yang lebih utama dari pada yang utama, mengutamakan yang lebih penting dari pada yang penting, lebih mengutamakan yang wajib dari pada yang sunah dan lebih mengutamakan yang prisnip dari pada masalah furu'iyah. Dengan demikian, tidak boleh bertengkar karena masalah yang tidak prinsip seperti masalah memanjangkan jenggot atau mencukurnya, masalah model berpakaian, cadar dan lain-lain dari permasalahan furu'iyah. Maksud siap berbeda pada yang zhannî; tidak boleh fanatik dengan mazhab atau pendapat tertentu dalam masalah- 
masalah ijtihadî. Harus toleran terhadap perbedaan pendapat dalam masalah yang bersifat zhannî. ${ }^{19}$

Karenanya, ulama membuat suatu rumusan agar tidak terjebak pada sikap fanatisme terhadap satu pendapat. Sebaiknya harus dilihat dulu teks-nya, apakah teks termasuk dalam katagori nash yang qath'î atau zannî? Di dalam Islam dikenal istilah ajaran absolut yaitu nash al-Quran atau hadis Nabi yang mengandung satu makna yang dalam istilah ushul fiqih disebut qath'î al-dalâlah dan ada juga ajaran relatif yang mempunyai lebih dari satu makna yang dalam istilah ushul fikih dzannî al-dalâlah. ${ }^{20}$

Tegasnya, bahwa dalam hukum fikih itu ada dua katagori. Pertama, qath'î al-dalâlah dan kedua, zannî al-dalâlah.

Bagian pertama, berkenaan dengan pokok-pokok akidah dan muamalah yang disetujui bersama, apa pun mazhabnya. Bagian kedua, bertalian dengan cabang-cabang ( $\left.f u r u^{\prime}\right)$ dari pokok - pokok di atas yang memungkinkan terjadinya perbedaan. ${ }^{21}$ Seorang tidak dikatakan muslim lagi bila berbeda pada fikih yang pertama. Sementara pada pada fikih yang kedua boleh berbeda pendapat.

Fikih yang pertama adalah berkaitan dengan akidah, seperti percaya kepada Allah yang Maha Esa, Muhammad Rasulullah dan hari kebangkitan. Tentang salat, tidak ada perbedaan antara semua mazhab dalam hal bilangan rekaat, jumlah sujud, jumlah salat wajib, dan bagianbagian salat yang penting lainya. Perbedaan mulai terjadi pada rincian dari pokok-pokok itu. Semua sepakat salat dimulai dengan takbir, mereka berbeda dalam cara mengangkat tangan dalam takbir. Kita akan menemukan bahwa bagian pertama berdasarkan dalil-dalil qath'î dan bagian kedua berdasarkan dali-dalil zhannî.

Pada bagian kedua sepatutnya kita saling menghargai dan menggunakan perbedaan pendapat untuk pengembangan wawasan tentang hukum Islam. Bila terjadi perbedaan paham atau penafsiran pada hal-hal yang zhannî, kita harus menguji perbedaan itu lewat ukuran-ukuran naqli dan aqli yang kemudian mengambil pendapat yag 
paling kuat atau yang disebut dengan istilah tarjîh. Dengan ukuran naqli, artinya mencari dalil-dalil yang paling kuat lewat kritik hadis dan ilmuilmu al-Qur'an. Ukuran aqli diartikan sebagai metode dialektik untuk menguji konsistensi logis suatu proposisi, dan hanya boleh dilakukan setelah $i$ Kita bisa memilih pendapat yang paling kuat atau yang disebut dengan tarjîh. Tetapi betapa pun kuatnya, pendapat itu tetap zhannî. Di tengah-tengah umat, keyakinan kita harus diamalkan sejauh tidak merusak keutuhan dan persatuan umat atau tidak mendatangkan mudarat, karena kita berpegangan pada prinsip mendahulukan yang wajib dengan tetap menjaga hubungan silaturahmi dan kesatuan umat.

Karena alasan ini, sekalipun menurut Ibnu Mas'ud ra. dan Ibn Umar ra. salat zuhur dan asar di Mina harus di - qashar. Namun ketika Utsman bin Affan ra. salat empat rekaat, Ibn Mas'ud salat juga empat rekaat. Ketika ditegur ia menjawab, "Semua perselisihan itu jelek" (al-Ikhtilâf syar kuluh). Ibn Umar juga ikut salat empat rekaat, tetapi mengulangi salatnya dirumah sebagai bentuk kehati-hatian (ikhtiyâthî). ${ }^{22}$

Imam Syafi'i tidak membaca qunut pada salat subuh, ketika ditanya apakah Anda lupa membaca qunut, ia menjawab aku tidak lupa membaca qunut, tetapi karena menghormati makam Abu Hanifah yang tidak jauh dari situ (sebagaimana diketahui Abu Hanifah tidak mensunahkan qunut). Imam Abu Hanifah dan imam Syafi'i pernah salat dibelakang para imam di Madinah yang tidak membaca basmalah, baik sir (perlahan) maupun jahr (keras), padahal kedua imam ini mengaruskan pembacaan basmalah pada al-Fatihah. Imam Ahmad berpendapat, wajib wudhu bagi orang yang berbekam dan mengeluarkan darah. Ia pernah ditanya: Jika imam mengeluarkan darah, kemudian tidak berwudhu, apakah anda akan salat dibelakang dia? Imam Ahmad menjawab: Bagaimana aku tidak salat di belakang imam Malik dan Sa'id bin Musayyab? (kedua imam ini berpendapat tidak wajib wudhu bagi orang yang mengeluarkan darah). Tradisi ini selalu dilakukan para ulama terdahulu karena memikirkan kemaslahatan umat dan tidak merasa benar sendiri dengan pendapatnya. Jadi yang dipentingkan agar tidak fanatik mazhab 
atau fanatik terhadap satu pendapat, prinsip silaturahmi atau ukhuwwah harus lebih dikedepankan agar terhindar dari sikap radikalisme dan ekstremisme.

\section{Toleransi Beragama dalam Sorotan}

Penelitian dan kajian tentang hubungan muslim non-muslim untuk penguatan terhadap toleransi beragama telah banyak dilakukan oleh para akedemisi dan peneliti. Penelitian yang dilakukan oleh Center fo Religious and Cross-culture Studies (CRCS) UGM tentang Laporan Tahunan Kehidupan Beragama di Indonesia, mengungkapkan bahwa penting bagi kelompok mayoritas untuk meningkatkan etika toleransi bagi setiap umat beragama dalam peningkatan terhadap kehidupan masyarakat yang lebih baik. Sementara bagi minoritas penting untuk memperhatikan kearifan dalam berkomunikasi dengan kelompok lain. Bagi kelompok keagamaan yang ingin mendirikan rumah ibadah, diharapkan untuk menyelesaikan surat izinnya, kerap ada keluhan dalam perizinan, tapi adanya izin menghilangkan alasan untuk tidak terpenuhinya hak beribadah. Tanpa semangat toleransi dan kearifan, konflik antar agama semakin sulit dihindari.

Sedangkan untuk masalah konflik penodaan dan penistaan agama, harus mementingkan hak-hak sipil, politik, dan ekonomi warga pengungsi Ahmadiyah di Mataram oleh negara. Satu hal yang penting untuk dilakukan adalah menciptakan situasi yang kondusif tanpa intimidasi, kekerasan, dan situasi aman. Sedangkan yang menjadi catatan dari berbagai kasus di atas adalah peran pemerintah daerah yang kerap tunduk pada desakan massa, bahkan melanggar hukum dan putusan peradilan sekalipun.

Kajian lain terkait dengan hubungan antar umat bergama juga dilakukan oleh Ahmad Munjin Nasih dan Dewa Agung Gede Agung, yang menitikberatkan pada pola relasi umat Islam dan umat Hindu dalam kerangka penguatan terhadap toleransi agama di Malang Raya. Umat Hindu di Malang Raya merupakan komunitas minoritas, di 
mana secara umum mereka tinggal di kawasan pedesaan yang terletak di pinggiran kota. Selama ini relasi umat Hindu dengan umat Muslim sebagai umat mayoritas terjalin dengan baik dan harmonis. Salah satu indikatornya adalah dalam kurun waktu yang sangat lama hampir tidak pernah terdengar ada benturan horizontal antarumat sehingga mengganggu hubungan keduanya. ${ }^{24}$

Hal mendasar yang menjadi penyebab keharmonisan hubungan keduanya adalah adanya saling pengertian dan toleransi, serta dibentuknya sistem sosial yang disepakati bersama tanpa mengorbankan akidah masing- masing. Setidaknya terdapat empat kegiatan yang dilakukan oleh umat Muslim dan Hindu secara turun temurun yang menyebabkan mereka bias hidup rukun dan harmonis yaitu: 1) kegiatan desa, 2) kegiatan kenegaraan; 3) kegiatan keagamaan; dan 4) kegiatan pelestarian budaya lokal. ${ }^{25}$

Berdasarkan hasil penelitian Ebin E. Danius, ${ }^{26}$ yang membahas tentang hubungan Kristen-Islam pasca konflik di Tobelo Halmahera Utara, menunjukkan bahwa relasi Kristen-Islam telah mengalami proses kemunduran sebagai akibat dari beberapa kebijakan yang dilakukan oleh pemerintah terkait dengan hubungan antar agama. Kebijakankebijakan yang dikeluarkan oleh pemerintah dalam hal ini hanya merupakan faktorpemicu yang memberikan legitimasi bagi pembatasan hubungan antar agama. Faktor yang paling menentukan sebenarnya adalah berkembangnya ajaran-ajaran agama yang berdampak pada kecurigaan tertentu dari masing-masing pihak. Dengan kecurigaan yang demikian maka semua hal yang dilakukan oleh pihak lain dianggap sebagai sebuah upaya untuk mempengaruhi keyakinan agama yang dipegang oleh mereka.

Upaya untuk menjalin relasi kembali sesudah konflik dilakukan dengan pendekatan kekerabatan dan ikatan kesukuan. Dalam beberapa hal pendekatan seperti ini cukup berhasil dalam menjembatani hubungan dua komunitas yang pernah berhadapan dalam konflik. Namun juga 
tidak bisa disangkal bahwa pengalaman konflik mendatangkan trauma tertentu yang berdampak pada kecurigaan-kecurigaan dari masingmasing pihak. Agama masing-masing komunitas dalam hal ini tetap menjadi sandaran utama dalam berhadapan dengan pihak lain yang berbeda agama.

\section{Landasan Teologis Hubungan Muslim Non-Muslim}

Beberapa ayat yang dapat dijadikan sebagai penguatan terhadap landasan teologis demi untuk mewujudkan hubungan muslim non-muslim menjadi harmonis dan inklusif sebagai berikut;

\section{Pertama;}

Berbuat baik dan bersikap adil suatu kewajiban yang harus dilaksanakan oleh seorang muslim sekalipun terhadap non-muslim, selagi mereka tidak menghalangi dakwah dan memerangi kita.

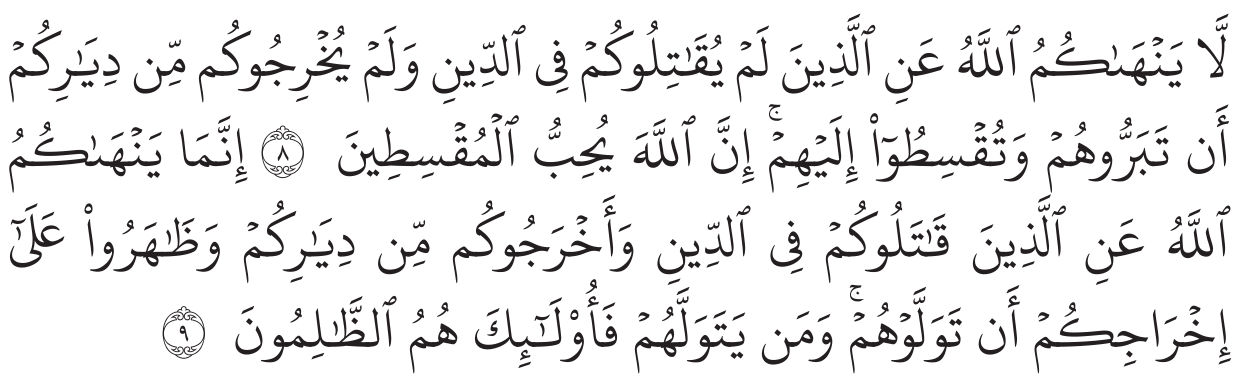

Artinya: "Allah tidak melarang kamu untuk berbuat baik dan berlaku adil terhadap orang-orang yang tiada memerangimu Karena agama dan tidak (pula) mengusir kamu dari negerimu. Sesungguhnya Allah menyukai orang-orang yang berlaku adil. Sesungguhnya Allah Hanya melarang kamu menjadikan sebagai kawanmu orang-orang yang memerangimu Karena agama dan mengusir kamu dari negerimu, dan membantu (orang lain) untuk mengusirmu. dan barangsiapa menjadikan mereka sebagai kawan, Maka mereka Itulah orangorang yang zalim" (QS. Al-Mumtahanah/60: 8-9) 
Kedua;

Al-Quran melarang berdialog dengan non-Muslim khususnya Ahlul Kitab kecuali dengan jalan yang baik.

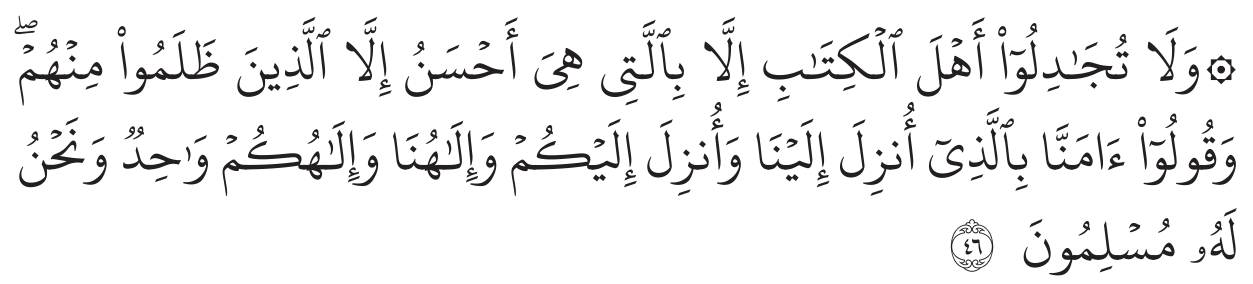

Artinya: "Dan janganlah kamu berdebat dengan Ahlul kitab, melainkan dengan cara yang paling baik, kecuali dengan orang-orang zalim di antara mereka, dan Katakanlah: "Kami Telah beriman kepada (kitab-kitab) yang diturunkan kepada kami dan yang diturunkan kepadamu; Tuhan kami dan Tuhanmu adalah satu; dan kami Hanya kepada-Nya berserah diri» (QS. AlAnkabût/29; 46)

Ketiga;

Al-Qur'an membolehkan makan hasil sembelihan Ahlul Kitab bahkan membolehkan kawin dengan perempuan-perempuan mereka yang baikbaik.

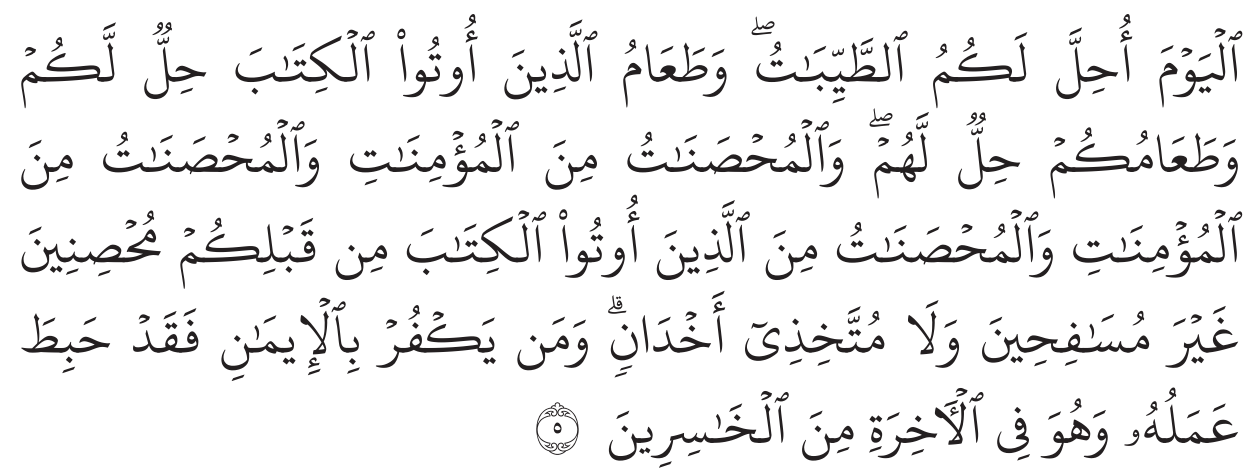

Artinya: "Pada hari Ini dihalalkan bagimu yang baik-baik. makanan (sembelihan) orang-orang yang diberi Al Kitab itu halal bagimu, dan makanan 
kamu halal (pula) bagi mereka. (dan dihalalkan mangawini) wanita yang menjaga kehormatan diantara wanita-wanita yang beriman dan wanita-wanita yang menjaga kehormatan di antara orang-orang yang diberi Al Kitab sebelum kamu, bila kamu Telah membayar mas kawin mereka dengan maksud menikahinya, tidak dengan maksud berzina dan tidak (pula) menjadikannya gundik-gundik. barangsiapa yang kafir sesudah beriman (Tidak menerima hukum-hukum Islam) Maka hapuslah amalannya dan ia di hari kiamat termasuk orang-orang merugi" (QS. Al-Mâidah 5/: 5)

Ini semua sebagai bukti bahwa Islam sangat bertoleransi terhadap kelompok di luar kita khususnya Ahlul Kitab.

Bahkan ada contoh kasus yang terjadi dalam suasana perang. Dikisahkan bahwa seorang tentara non-Muslim menemui Ummu Hânî binti Abû Thâlib. Dia meminta perlindungan kepadanya. Ketika beberapa sahabat Nabi keberatan dan ingin membatalkannya, dia marah dan mengadu kepada Nabi. Kemudian Nabi berkata: “Wahai Ummu Hânî, kami memberi perlindungan kepada siapapun yang engkau beri perlindungan. ${ }^{27}$ Artinya, Nabi membenarkan tindakan Ummu Hânî yang memberikan perlindungan, karena orang itu memang membutuhkan perlindungan.

Dalam surat at-Taubah disebutkan;

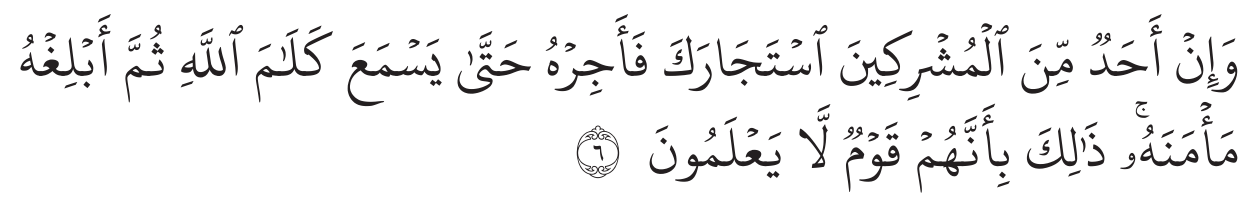

Artinya: "Dan jika seorang diantara orang-orang musyrikin itu meminta perlindungan kepadamu, Maka lindungilah ia supaya ia sempat mendengar firman Allah, Kemudian antarkanlah ia ketempat yang aman baginya. demikian itu disebabkan mereka kaum yang tidak Mengetahui" (QS. Al-Taubah/9: 6)

Berdasarkan ayat di atas bisa dijelaskan bahwa al-Qur'an menegaskan, bukan saja disuruh melindungi orang-orang musyrik dan memberi nasehat agar mereka mau mendengarkan kebenaran, tetapi lebih dari 
itu, umat Islam juga disuruh agar menjamin keamanan mereka dan mengantarkannya ke tempat yang aman.

Banyak isyarat al-Qur'an agar umat Islam berpegang teguh pada ajaran Islam (tegas) dan pada saat yang bersamaan juga bisa bersikap toleran kepada agama lain. Sebagai mana kedua kewajiban ini tergambar dalam firman Allah berikut ini:

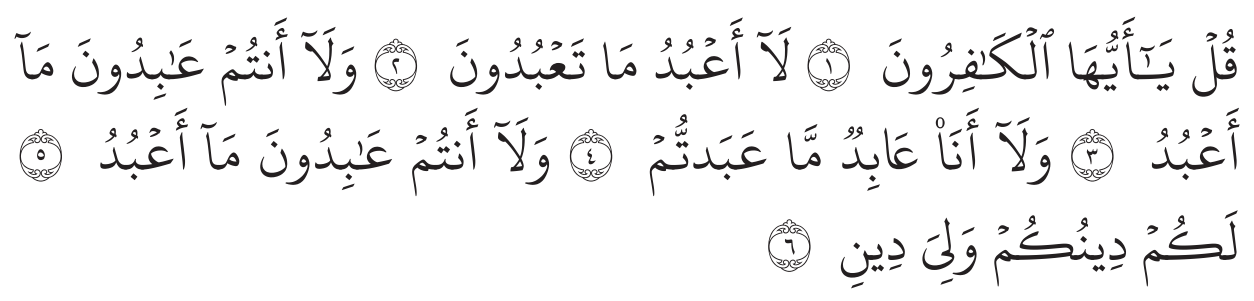

Artinya: "Katakanlah: «Hai orang-orang kafir, Aku tidak akan menyembah apa yang kamu sembah. Dan kamu bukan penyembah Tuhan yang Aku sembah. Dan Aku tidak pernah menjadi penyembah apa yang kamu sembah. Dan kamu tidak pernah (pula) menjadi penyembah Tuhan yang Aku sembah. Untukmu agamamu, dan untukkulah, agamaku» (QS. Al-Kâfirûn/109: 1-6)

Ayat di atas menyuruh umat agar berpegang teguh dengan ajaran Islam. Tetapi, pada akhir ayat ditegaskan keharusan bersikap toleran seperti dalam firman-Nya; "Untukmulah agamamu dan untukku lah agamaku." (QS. Surat Al-Kâfirûn/109: 6)

Setiap pemeluk agama bebas untuk tumbuh dan hidup karena semuanya akan dipertanggungjawabkan kelak di akhirat di hadapan Allah SWT.

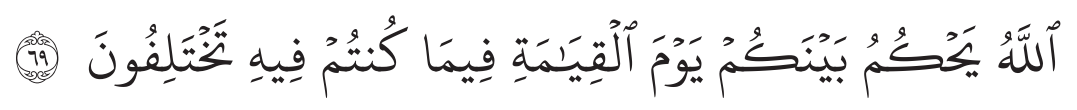

Artinya: "Allah akan mengadili di antara kamu pada hari kiamat tentang apa yang kamu dahulu selalu berselisih padanya" (QS. Al-Hajj/22: 69)

Bersikap toleransi adalah sikap yang dianjurkan oleh akidah dan ajaran Islam. Dengan beberapa alasan berikut ini: 
Pertama, seorang muslim meyakini bahwa kitab suci yang senantiasa dibacanya itu menyatakan dengan jelas adanya ragam agama manusia. Kenyataan ini merupakan kenyataan yang dikehendaki Allah. FirmanNya,

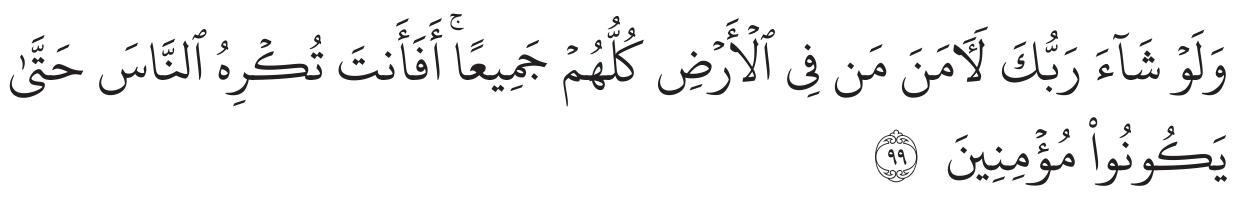

Artinya: "Dan jikalau Tuhanmu menghendaki, tentulah beriman semua orang yang dimuka bumi seluruhnya. Maka apakah kamu (hendak) memaksa manusia supaya mereka menjadi orang-orang yang beriman semuanya?" (QS. Yûnus /10: 99)

Kedua, pertanggungjawaban bahwa seseorang adalah kufur dan sesat bukanlah dikehidupan ini. Melainkan kelak dihari terakhir disaat semua perbuatan dipertanggungjawabkan dihadapan Allah seperti ditegaskan dalam ayat al-Qur'an:

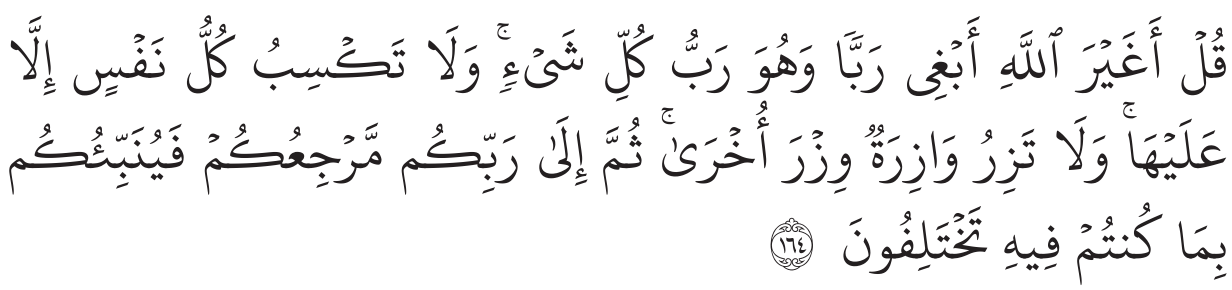

Artinya: "Katakanlah: "Apakah Aku akan mencari Tuhan selain Allah, padahal dia adalah Tuhan bagi segala sesuatu. dan tidaklah seorang membuat dosa melainkan kemudharatannya kembali kepada dirinya sendiri; dan seorang yang berdosa tidak akan memikul dosa orang lain. Kemudian kepada Tuhanmulah kamu kembali, dan akan diberitakan-Nya kepadamu apa yang kamu perselisihkan.» (QS. Al-An'âm/6: 164)

Ketiga, seorang muslim diperintahkan agar mampu berbuat adil kepada semua orang termasuk terhadap non - muslim khususnya Ahlul Kitab. Allah berfirman, 


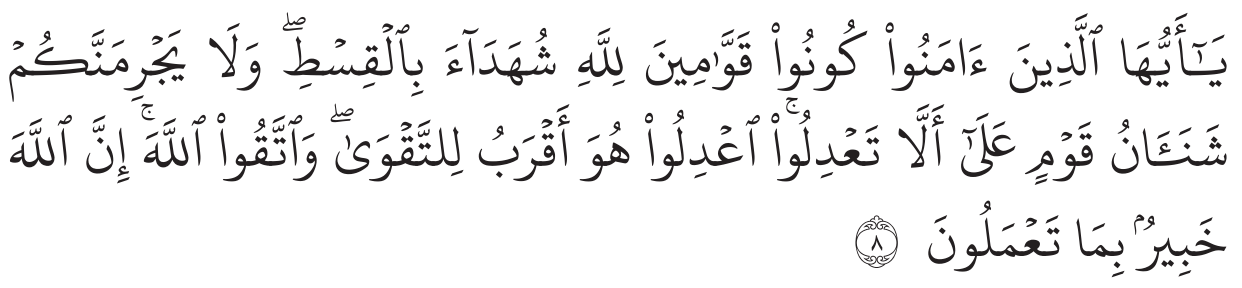

Artinya: "Hai orang-orang yang beriman, hendaklah kamu menjadi orangorang yang selalu menegakan (kebenaran)karena Allah, menjadi saksi dengan adil. Dan janganlah sekali-kali kebencian terhadap sesuatu kaum, mendorong kamu untuk berlaku tidak adil. Berlaku adilah, karena adil itu lebih dekat kepeda takwa. Dan bertakwalah kepada Allah, sesungguhnya Allah Maha Mengetahui apa yang kamu kerjakan," (QS. Al-Mâidah/5: 8)

Beberapa ayat di atas mesti dipahami secara seksama dan mendalam demi penguatan teologis untuk membangun toleransi beragama. Bahkan dalam keterangan lain Rasul pun mencontohkan sikap seperti ini. Nabi Muhammad - yang merupakan salah satu bentuk penjelasan dan penafsir al-Quran - dalam menghadapi non-muslim.

\section{Penafsiran Antara Teks dan Konteks}

Dalam membangun kerukunan antar - umat beragama, jelas yang dibutuhkan adalah kehadiran tafsir al-Qur'an yang lebih menghargai umat lain. Tafsir al-Qur'an yang kontektualis dan inklusif sehingga dapat memberikan pemahaman keagamaan yang bernuansa damai, toleran, dan sejuk serta menguntungkan bagi semua pihak dalam menjalani kehidupan berbangsa dan bernegara sesuai dengan spirit ke- Bhinekaan, UUD ‘ 45 dan dasar negara kita Panca Sila.

Dalam teks-teks keagamaan (al-nushûs al-dîniyah), baik dalam al-Quran maupun Hadis, disatu sisi memiliki karakter-karakter keras. Namun di sisi lain teks-teks agama juga memiliki karakter-karakter lunak.

Di antara ayat yang berkarakter keras seperti firman Allah SWT;

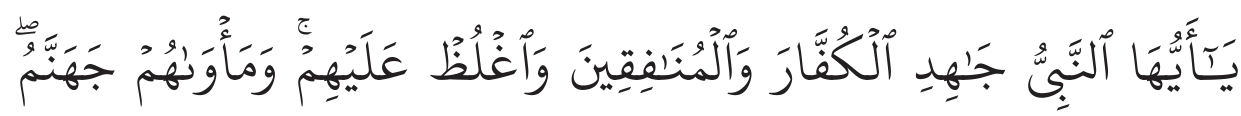




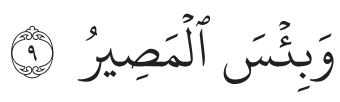

Artinya: "Hai Nabi, perangilah orang-orang kafir dan orang-orang munafik dan bersikap keraslah terhadap mereka. Tempat mereka adalah neraka Jahanam dan itu adalah seburuk-buruk tempat kembali" (QS. Al-Tahrim/66: 9)

Di antara contoh Hadis Nabi dari Ibn Umar ra. yang berkarakter keras, riwayat Imam Muslim:

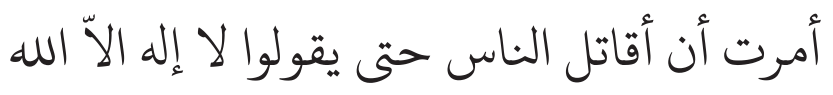

Artinya: "Aku diperintahkan untuk memerangi mansusia sampai mereka mengatakan 'lâ ilâha illa Allâh' (tidak ada Tuhan selain Allah)". (HR. Bukhari - Muslim). ${ }^{28}$

Dari dua contoh teks agama di atas, Islam tergambar dengan wajahnya yang sangat sadis dan jauh dari sikap toleran, karena orang-orang nonmuslim secara mutlak harus diperangi atau dibunuh.

Dalam konteks surat al-Tahrim ayat 9 Nabi harus memerangi orang kafir (non-muslim) dan orang-orang munafik, dalam situasi apapun, karena ayat-ayat tersebut tidak memberikan batasan-batasan situasi. Demikian pula Hadis riwayat Muslim yang menerangkan bahwa Nabi SAW diperintahkan untuk memerangi manusia sampai mereka mengucapkan kalmat 'lâ ilâha illa Allâh'. Ini artinya bahwa Nabi SAW tidak memiliki opsi lain dalam menghadapi non-muslim (orang kafir) kecuali memerangi mereka sampai habis.

Namun demikian, jika memperhatikan perilaku Nabi Muhammad yang merupakan salah satu bentuk penjelasan dan penafsir al-Qur'an dalam menghadapi non-muslim tidak seperti itu. Nabi justru rumahnya terbuka buat non-muslim. Bahkan salah satu mertua Nabi SAW yang bernama Huyay bin Ahthab adalah seorang tokoh Yahudi dari Bani Quraidhah dan Nabi sangat hormati kepadanya. Dalam Shahîh Bukhâri dan Shahîh Muslim ada keterangan bahwa Ummul Mukminin 'Aisyah istri Nabi Muhammad SAW sering mengobrol dan berdiskusi dengan 
wanita-wanita Yahudi di rumah Nabi. Diskusi mereka terkadang juga melibatkan Nabi dalam masalah-masalah agama. Wanita-wanita Yahudi datang ke rumah Nabi itu terkadang sendiri dan terkadang lebih dari satu (kelompok). ${ }^{29}$

Nabi Muhammad SAW juga membiarkan orang-orang Nasrani Najran hidup berdampingan dengan umat Islam, mereka tidak diperangi oleh Nabi. Demikian pula orang Majusi yang tinggal dikawasan Hajar, daerah Timur Jazirah Arab dibiarkan hidup oleh Nabi SAW. Bahka pada saat akhir kehidupan Nabi, beliau masih melakukan transaksi dengan seorang non-muslim. Nabi SAW meminjam gandum 30 sha' (sekitar 75 $\mathrm{kg}$ ) dari seorang Yahudi bernama Abu Shahm dengan menggadaikan baju perang beliau. ${ }^{30}$

Sebuah peristiwa yang dikisahkan oleh Ibn Ishak dalam al-Syîrah al-Nabawiyah, bahwa Nabi pernah menerima kunjungan para tokoh Kristen Najran yang berjumlah 60 orang. Rombongan dipimpin Abd al - Masih al-Ayham dan Abu Harithah bin Alqama. Abu Harithah adalah tokoh yang sangat disegani karena kedalaman ilmunya dan konon karena beberapa karomah yang dimilikinya. Menurut Muhammad ibn Ja'far ibn al-Zubair, ketika rombongan itu sampai ke Madinah, mereka langsung menuju Masjid padahal Nabi sedang melaksanakan salat asar. Mereka memakai jubah dan surban. Ketika waktu kebaktian telah tiba, mereka pun melakuaknnya di dalam mesjid dengan menghadap ke arah timur. ${ }^{31}$ Hal itu mengindikasikan, betapa Rasul sangat menghargai dan mentoleransi bahkan dalam soal ritus peribadatan.

Lebih dari itu Nabi mengatakan:

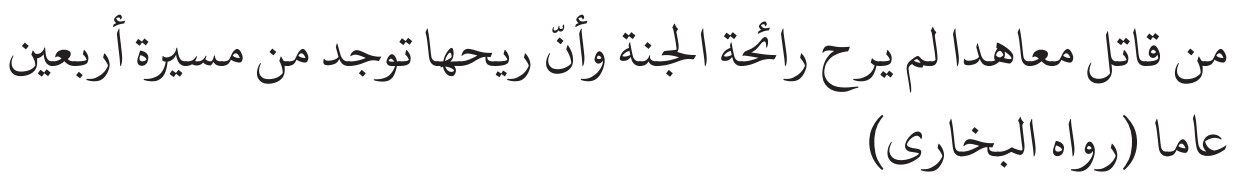

Artinya: "Siapa yang membunuh orang kafir mu'âhad (yang terikat janji), ia tidak akan mencium aroma surga, dan aroma surga itu dapat dicium dari jarak perjalanan empat puluh tahun" (HR. Bukhari) ${ }^{32}$ 
Dengan demikian, ayat dan hadis di atas mesti dipahami secara kontekstual dan komprehensif tidak sepotong-sepotong. Dalam tataran praksis, mesti memperhatikan antara ayat-ayat al-Quran dan Hadis Nabi yang turun dalam kondisi perang dan ayat-ayat al-Quran dan Hadis Nabi yang turun dalam kondisi damai.

Ayat-ayat al-Quran dan Hadis Nabi yang berkaitan dengan konteks perang, harus diposisikan pada situasi perang dan digunakan hanya untuk menghadapi orang-orang yang memerangi Islam. Sementara ayat-ayat al-Quran dan Hadis Nabi yang berkaitan dengan konteks dan situasi damai, mesti diposisikan pada situasi damai. Begitu juga sebaliknya. Membalik penerapan tersebut yaitu menggunakan ayat-ayat al-Quran dan Hadis Nabi yang konteksnya dalam situasi perang untuk situasi damai dan atau menerapkan ayat-ayat al-Quran dan Hadis Nabi yang berkaitan konteks damai untuk situasi perang, hal itu sama halnya dengan memutar balikan dan mengacaukan ajaran Islam. Ayat tersebut mesti ditafsirkan berdasarkan konteks zaman-nya.

\section{Penutup}

Berdasarkan pembahasan di atas, dapat ditarik kesimpulan, bahwa pola mewujudkan moderasi kehiudpuna beragama mesti dimulai melalui pemahaman agama yang moderat, kontektual, dan komprehensif, tidak fanatik, kaku dan mempersulit diri serta memberi tempat pada penguatan landasan teologis hubungan muslim non-muslim untuk mendukung upaya mewujudkan sikap keterbukaan demi menggapai masyarakat yang toleran - inklusif.

Sejarah konflik antar umat beragama dimanapun, yang telah membuahkan kesalah pahaman, rasa curiga, dan bahkan permusuhan mesti dibuang jauh-jauh dari pikiran kita. Para pemeluk agama benarbenar dituntut untuk memperdalam, mempererat, memperkuat toleransi beragama dan mewujudkan semangat persaudaraan universal dalam kehidupan riil demi menuju masyarakat moderat dan inklusif. 
Diharapkan sikap seperti ini dapat mengubah ketegangan hidup beragama yang dirasakan ada dalam masyarakat kita sekarang dan terciptanya sikap keterbukaan.

Dalam membangun kerukunan antar - umat beragama, jelas yang dibutuhkan adalah kehadiran tafsir al-Quran yang lebih menghargai umat lain. Tafsir al-Quran yang inklusif dan dapat memberikan pemahaman keagamaan yang bernuansa damai, toleran, dan sejuk serta menguntungkan bagi semua pihak, sehingga kehidupan berbangsa dan bernegara dapat dijalani secara produktif dan harmonis.

Namun juga tidak bisa disangkal bahwa pengalaman konflik mendatangkan trauma tertentu yang berdampak pada kecurigaankecurigaan dari masing-masing pihak. Agama masing-masing komunitas dalam hal ini tetap menjadi sandaran utama dalam berhadapan dengan pihak lain yang berbeda agama. Di samping mesti diperkuat juga oleh sistem dan tatanan serta dukungan pemerintah dalam membangun kerjasama dengan para tokoh agama serta memperkuat aspek kehidupan sosial di masyarakat. 


\section{Daftar Pustaka}

Abdul Malik, Abu Muhammad ibn Hisyâm al-Ma'ârif, Al-Sîrah alNabawiyah. Kairo: Dâr al-Hadîth, 2004.

Danius, Ebin E, "Hubungan Kristen-Islam Pasca Konflik di Tobelo Halmahera Utara." Jurnal Uniera, vol 1 no 1, 2012.

Hapsin, Abu, Komaruddin, M. Arja Imroni. “Urgensi Regulasi Penyelesaian Konflik Umat Beragama: Perspektif Tokoh Lintas Agama". Jurnal Walisongo, vol. 22. No. 2 , 2014.

Kementerian Agama RI. Potret Kerukunan Umat Beragama Di Provinsi Jawa Timur. Jakarta: Badan Litbang dan Diklat Puslitbang Keagamaan Kementerian Agama RI, 2011.

Al-Maghribi, Abdul Qadir, "Muhamad dan Women", dalam Charles Kurzman, ed., Modernist Islam, 1840-1940. New York: Oxpord University Press, 2002.

Nasih, Ahmad Munjin dan Dewa Agung Gede Agung, "Harmoni Relasi Sosial Umat Muslim dengan Hindu di Malang Raya". Jurnal Masyarakat, Kebudayaan dan Politik, vol 24 no 2 tahun 2011.

Al-Nawawi, Al-Muhyi bin Sharaf Al-Din, Sharh al-Arba'in Hadithan alNawawiyah, Pentahqiq: Ibn al-Daqiq al-'Ied.

Al-Qardhawi, Yusuf, Al-Shahwah Al-Islâmiyah Baina Al-Ikhtilâf AlMasyrû' wa Al-Tafarruq Al-Madzmûm.. Kairo: Dâr Al-Shahwah. 1994.

, Fî Fiqh Al-Aulawiyyât; Dirâsah Jadîdah Fî Dhau' AlQur'an wa Al-Sunnah. Kairo: Maktabah Wahbah, 1995.

Al-Shahwah Al-Islamiyah Baina al-Jumud wa alTatharruf, Kairo: Dar al-Syuruq, 2001. 
Rakhmat, Jalaluddin, Dahulukan Akhlak di atas Fikih, Bandung: Muthahari Press, 2003.

Toha, Suhermanto, dkk. "Eksistensi Surat Keputusan Bersama Dalam Penyelesaian Konflik Antar Dan Intern Agama." Laporan Akhir Penelitian Hukum. Jakarta: Badan Pembinaan Hukum Nasional Kementerian Hukum dan HAM RI.

Tim Penyusun Kementerina Agama RI, Moderasi Beragama, Jakarta: Badan Litbang dan Diklat Kementerian Agama RI 2019.

Zainal Abidin, Bagir, dkk., Laporan Tahunan Kehidupan Beragama Di Indonesia, Yogyakarta: Program Studi Agama dan Lintas Budaya, 2010.

Zuhaili, Wahbah, Al-Wajîz, fî Ushûl al-Fiqh, Baerut: Dâr Al-Fikr AlMu'âshir, 1995.

\section{INTERNET}

Tindakan intoleran naik 30\% dalam http://www. menkokesra. go.id/ content/ tinda kan-intoleran-naik-30\%. Diakses tanggal 9 Juni 2014.

Kusumadewi, Anggi dan Ryan Dwi, “2014, Ada Enam Kasus Intoleransi di Jawa Tengah," dalam http://nasional.news.viva.co.id/news/ $\mathrm{read} / 509782-2014$--ada- enam-kasus-intoleransi-di-jawa-tengah .Diakses tanggal 9 Juni 2014. 


\section{Endnotes}

1. Suhermanto Toha, dkk., "Eksistensi Surat Keputusan Bersama Dalam Penyelesaian Konflik Antar Dan Intern Agama" (Jakarta: Badan Pembinaan Hukum Nasional Kementerian Hukum dan HAM RI, 2011), 1-2. (Laporan Akhir Penelitian Hukum)

2. Kementerian Agama RI, Potret Kerukunan Umat Beragama DI Provinsi Jawa Timur (Jakarta: Badan Litbang dan Diklat Puslitbang Keagamaan Kementerian Agama RI, 2011), 2.

3. Toha, “Eksistensi....", 2.

4. “Tindakan intoleran naik 30\% dalam http://www.menkokesra.go.id/ content/tindakan-intoleran-naik-30\%. (Diakses tanggal 9 Juni 2014).

5. Anggi Kusumadewi dan Ryan Dwi, “2014, Ada Enam Kasus Intoleransi di Jawa Tengah," dalam http://nasional.news.viva.co.id/news/read/5097822014--ada- enam-kasus-intoleransi-di-jawa-tengah (Diakses tanggal 9 Juni 2014).

6. Abu Hapsin, Komaruddin, M. Arja Imroni. “Urgensi Regulasi Penyelesaian Konflik Umat Beragama: Perspektif Tokoh Lintas Agama". Jurnal Walisongo, vol. 22. No. 2 Tahun 2014, 352.

7. Tim Penyusun Kementerina Agama RI, Moderasi Beragama (Jakarta: Badan Litbang dan Diklat Kementerian Agama RI 2019), 16-17.

8. Tim Penyusun Kemenag, Moderasi Beragama, 17.

9. Yusuf al-Qardhawi, Al-Shahwah Al-Islamiyah Baina al-Jumud wa al-Tatharruf (Kairo: Dar al-Syuruq, 2001), 30-40.

10. Al-Qardhawi, Al-Shahwah Al-Islamiyah Baina al-Jumud, 26.

11. Al-Qardhawi, Al-Shahwah Al-Islamiyah Baina al-Jumud, 27.

12. Al-Qardhawi, Al-Shahwah Al-Islamiyah Baina al-Jumud, 27.

13. Al-Qardhawi, Al-Shahwah Al-Islamiyah Baina al-Jumud, 27. 
14. Yang dimaksud dengan Islam zaman klasik di sini adalah era pemikiran rasional yang amat dominan ketika itu. Dimana perbedaan pendapat sangat di hormati, perbedaan budaya tidak menjadi soal, sikap keterbukaan sangat dijunjung tinggi dan ilmu pengetahuan telah mencapai puncaknya. Hal itu berlangsung sekitar tahun 650-1250 M.

15. Al-Qardhawi, Al-Shahwah Al-Islamiyah Baina al-Jumud, 30-40

16. HR. Bukhari-Muslim dari Aisyah ra. sebagaimana dikutip al-Qardhawi dalam bukunya Al-Shahwah Al-Islamiyah Baina al-Jumud, 37-38.

17. HR. Bukhari seperti dikutip al-Qardhawi dalam bukunya Al-Shahwah AlIslamiyah Baina al-Jumud, 37.

18. HR. Bukhari - Muslim seperti dikutip al-Qardhawi dalam bukunya AlShahwah Al-Islamiyah Baina al-Jumud, 40.

19. Yusuf al-Qardhawi, Al-Shahwah Al-Islâmiyah Baina Al-Ikhtilâf Al-Masyrû' wa Al-Tafarruq Al-Madzmûm (Kairo: Dâr Al-Shahwah. 1994), 145-173.

20. Wahbah Zuhaili, Al-Wajîz, fî Ushûl al-Figh (Baerut: Dâr Al-Fikr Al-Mu'âshir, 1995), 32-33.

21. Yusuf al-Qardhawi, Fî Figh Al-Aulawiyyât; Dirâsah Jadîdah Fî Dhau' Al-Qur'an wa Al-Sunnah (Kairo: Maktabah Wahbah, 1995), 76-80.

22. Jalaluddin Rakhmat, Dahulukan Akhlak di atas Fikih (Bandung: Muthahari Press, 2003), 44-45.

23. Lihat Bagir, Zainal Abidin, dkk., "Laporan Tahunan Kehidupan Beragama Di Indonesia" (Yogyakarta: Program Studi Agama dan Lintas Budaya, 2010).

24. Ahmad Munjin Nasih dan Dewa Agung Gede Agung, “Harmoni Relasi Sosial Umat Muslim dengan Hindu di Malang Raya"Jurnal Masyarakat, Kebudayaan dan Politik, vol 24 no 2 tahun 2011.

25. Ahmad Munjin Nasih dan Dewa Agung Gede Agung, "Harmoni Relasi Sosial Umat Muslim dengan Hindu di Malang Raya". Jurnal Masyarakat, Kebudayaan dan Politik, vol 24 no 2 tahun 2011.

26. Ebin E Danius, "Hubungan Kristen-Islam Pasca Konflik di Tobelo Halmahera Utara." Jurnal Uniera, vol 1 no 1, Tahun 2012.

27. Abdul Qadir al-Maghribi "Muhamad dan Women", dalam Charles 
Kurzman, ed., Modernist Islam, 1840-1940 (New York: Oxpord University Press, 2002), 211.

28. HR. Bukhari - Muslim. Di kutip dari kitab Al-Muhyi bin Sharaf Al-Din AlNawawi, Sharh al-Arba'in Hadithan al-Nawawiyah, Pentahqiq: Ibn al-Daqiq al'Ied. Hadis ke 8, 29.

29. Ummul Mukminin Aisyah menuturkan, "Ketika Nabi SAW masuk ke rumahku, aku sedang duduk-duduk bersama seorang wanita Yahudi. Wanita Yahudi itu berkata, tahukah kamu bahwa kalian nanti akan mendapat siksa kubur? Mendengar kata-kata itu Nabi SAW terkejut kemudian beliau bersabda, "Justru orang-orang Yahudi yang akan mendapatkan siksa kubur". Aisyah selanjutnya mengatakan, beberapa hari kemudian Nabi berkata: "Tahukah kamu bahwa aku diberi wahyu oleh Allah yang isinya bahwa kalian (umat Islam) akan mendapatkan sisksa kubur? Maka sejak itu Nabi SAW. selalu meminta perlindungan kepada Allah SWT. dari siksa kubur.

30. 30 Ibn Hajar al-Atsqalani, Fath al-Bari bi Syarh Shahih al-Bukhari (Riyad: Maktabah Malik Fahd, 2001), dalam Kitab al-Rahn fi al-Hadhar, j, V, 167.

31. 31 Abu Muhammad Abd al-Malik Ibn Hisyâm al-Ma'ârif, Al-Sîrah alNabawiyah (Kairo: Dâr al-Hadîts, 2004), j, II, 426-428.

32. 32 Abu Abd Allah bin Muhammad bin Isma'il al-Bukhari, Al-Jami' AlShahih (Kairo: Al-Maktabah Al-Salafiyah, 1403 H), c, I, 409 dalam Bab Itsm Man Qatala Mu'ahidan bi Ghairi Jurmin, no hadis ke 3166. 